\title{
Penerapan Konsep Object Oriented Programming Untuk Aplikasi Pembuat Surat
}

\author{
Muh. Rais \\ Fakultas Teknik dan Informatika, \\ Universitas Patria Artha \\ muh.raisazisnawawi@gmail.com
}

\begin{abstract}
Jenis penelitian ini adalah eksperimental yaitu dengan melakukan perancangan, pembuatan dan pengujian model sistem. Aplikasi penilaian persentasi mahasiswa ini bertujuan untuk membuat surat surat keputusan penugasan dosen pengajar dan membuat penomoran secara otomatis. Metode pngujian pada sistem ini menggunakan pengujian black box, yang berfokus pada persyaratan fungsional perangkat lunak untuk mengetahui apakah fungsi tersebut berfungsi sesuai dengan yang diharapkan atau tidak. Dari hasil pengujian black box, keseluruhan sistem dapat berfungsi dengan baik. Aplikasi yang dibangun dengan menerapkan OOP dapat menghemat waktu dan mudah dalam mendeteksi error. Aplikasi ini sangat membantu dalam pembuatan surat, serta mencegah penomoran yang sama pada surat.
\end{abstract}

\section{PENDAHULUAN}

Pada saat ini, metode berorientasi objek atau dikenal Dengan Object Oriented Programming (OOP) banyak dipilih karena metodologi lama banyak menimbulkan masalah seperti adanya kesulitan pada saat mentransformasi hasil dari satu tahap pengembangan ke tahap berikutnya, misalnya pada metode pendekatan terstruktur.

Salah satu kelebihan metode OOP adalah pendekatan pengembangan lebih dekat dengan dunia nyata dan adanya konsistensi pada saat pengembangannya, perangkat lunak yang dihasilkan akan maupun memenuhi kebutuhan pemakai serta mempunyai sedikit kesalahan [1].

Pada era globalisasi teknologi komputer memegang peranan yang sangat penting untuk membantu proses aktivitas kerja di instansi maupun diperkantoran baik dari lembaga pemerintah maupun swasta. Penggunaan perangkat komputer sebagai perangkat pendukung menajemen dan pengolahan data adalah sangat tepat dengan pertimbangkan perangkat komputer dalam setiap informasi sangat diperlukan dalam kegiatan manajemen atau perkantoran [2].

Penggunaan teknologi komputer sebagai alat teknologi informasi dalam dunia perkantoran memberikan nilai tambah proses pengolahan data, dalam dunia perkantoran keberadaan teknologi informasi juga sangat berguna bagi pihak instansi untuk mempermudah kinerja dalam kegiatan sehari-hari salah satu contohnya dalam hal pembuatan surat [3].

Surat adalah sarana dalam berkomunikasi yang digunakan untuk menyampaikan informasi tertulis oleh suatu pihak ke pihak lain. Informasi yang disampaikan melalui surat dapat berbentuk pemberitahuan, pernyataan, perintah, atau laporan. Meskipun teknologi komunikasi berkembang sangat pesat, peran surat belum dapat tergantikan [1].

Di prodi Teknik Informatika, Universitas Patria Artha proses pembuatan surat masih menggunakan Microsoft Word. Hal ini tentunya kurang effisein, salah satu contohnya adalah dalam pembuatan penomoran surat yang masih dilakukan secara manual. Oleh karena itu perlu adanya sebuah aplikasi yang dapat membuat surat untuk membantu kinerja dosen dalam proses pembuatan surat.

\section{TINJAUAN PUSTKA}

1. Object Oriented Programming

Object Oriented Programming (OOP) adalah suatu strategi pembangunan perangkat lunak yang mengorganisasikan perangkat lunak sebagai kumpulan objek yang berisi data dan operasi yang diberlakukan terhadapnya. Object Oriented Programing atau yang disingkat OOP ialah paradigma atau tehnik pemograman yang berorientasi kepada objek [4].

Berdasarkan pengertian yang ada dapat disimpulkan bahwa Object Oriented Programing (OOP) merupakan suatu strategi atau cara baru untuk membuat program atau merancang sistem dengan memperhatikan objek.

Pada saat ini, metode berorientasi objek banyak dipilih karena metodologi lama banyak menimbulkan masalah seperti adanya kesulitan pada saat mentransformasi hasil dari satu tahap pengembangan ke tahap berikutnya, misalnya pada metode pendekatan terstruktur, jenis aplikasi yang dikembangkan saat ini berbeda dengan masa lalu. Aplikasi yang dikembangkan pada saat ini sangat beragam (aplikasi bisnis, real-time, utilty, dan sebgaianya) dengan platform yang berbedabeda, sehingga menimbulkan tuntutan kebutuhan 
metodologi pengembangan yang dapat mengakomodasi ke semua jenis aplikasi tersebut.

Keuntungan menggunakan metodologi berorientasi objek adalah sebagai berikut:

a. Meningkatkan produktivitas

Karena kelas dan objek yang ditemukan dalam suatu masalah masih dapat dipakai ulang untuk masalah lainnya yang melibatkan objek tersebut (reusable).

b. Kecepatan pengembangan

Karena sistem yang dibangun dengan baik dan benar pada saat analisis dan peracangan akan menyebabkan berkurangnya kesalahan pada pengkodean.

c. Kemudahan pemiliharaan

Karena dengan model objek, pola-pola yang cenderung tetap dan stabil dapat dipisahkan dan pola-pola yang mungkin sering berubah-ubah.

d. Adanya konsistensi

Karena sifat pewarisan dan penggunaan notasi yang sama pada saat analisis, perancangan maupun pengkodean.

e. Meningkatkan kualitas perangkat lunak

Karena pendekatan pengembangan lebih dekat dengan dunia nyata dan adanya konsistensi pada saat pengembangannya, perangkat lunak yang dihasilkan akan maupun memenuhi kebutuhan pemakai serta mempunyai sedikit kesalahan.

Pemograman OOP merupakan pendekatan yang melihat sebuah permasalahan dan sistem pada objek. Memandang sistem berorientasi objek yang dikembangkan, sebagai kumpulan objek yang berkorespondensi dengan objek pada dunia nyata. Sistem yang berorientasi objek ini, memiliki fungsi serta datadata dikelompokkan dalam sebuah komponen yang dibungkus (enkasulapsi) kedalam bentuk objek, sehingga setiap objek dapat mewariskan sifatnya atau setiap objek yang berbeda. Kumpulan dari objek-objek itu akan berinteraksi satu sama lainnya untuk menghasikan output yang diinginkan [2].

Metodologi pengembangan sistem yang berorientasi objek memiliki beberapa konsep dasar yang harus dipahami, meliputi:

a. Kelas (Class)

Kelas adalah kumpulan objek-objek dengan karakteristik yang sama. Kelas merupakan defenisi statik dan himpunan objek yang sama mungkin lahir atau diciptakan oleh kelas tersebut. Sebuah kelas mempunyai sifat (atribut), kelakuan (operasi/method), hubungan (relationship) dan arti. Suatu kelas dapat diturunkan kekelas yang lain, dimana atribut dan kelas semula dapat diwariskan kekelas yang baru.

b. Objek (Object)

Objek adalah abstraksi dan sesuatu yang mewakili dunia nyata seperti benda, manusia, satuan organisasi, tempat, kejadian, struktur, status, atau hal-hal lain yang bersifat abstrak. Objek merupakan suatu entitas yang mampu menyimpan informasi (status) dan mempunyai operasi (kelakuan) yang dapat diterapkan atau dapt brtpengaris pada statis objeknya. Objek mempunyai siklus hidup yaitu diciptakan, dimanipulasi dan dihancurkan.

c. Metode (Method)

Operasi atau metode atau method pada sebuah kelas hampir sama dengan fungsi atau prosedur pada metodologi struktural. Sebuah kelas boleh memiliki lebih dari satu metode atau operasi. Metode atau operasi yang berfungsi untuk memanipulasi objek itu sendiri. Operasi atau metode merupakan fungsi atau transformasi yang dapat dilakukan terhadap objek atau yang dilakukan oleh objek.

d. Atribut (Attribute)

Atribut dari sebuah kelas adalah variabel global yang dimiliki sebuah kelas. Atribut dapat berupa nilai atau elemen-elemen data yang dimiliki oleh objek dalam kelas objek. Atribut dipunyai secara individual oleh sebuah objek, misalnya berat, jenis, nama, dan sebagainya. Atribut sebaiknya bersifat privat untuk menjaga enkasulapsi.

e. Abstraksi (Abstraction)

Prinsip untuk mempresentasikan dunia nyata yang komplek menjadi suatu bentuk model yang sederhana dengan mengabaikan aspek-aspek lain yang tidak sesuai dengan permasalahan.

f. Enkapsulasi (Encapsulation)

Pembungkusan atribut data dan layanan (operasioperasi) yang dipunyai objek untuk menyembunyikan implementasi dan objek sehingga objek lain tidak mengetahui cara kerjanya.

g. Pewarisan (Inheritance)

Mekanisme yang memungkin suatu objek mewarisi sebagian atau seluruh defenisi dan objek lain sebagai bagian dari dirinya.

h. Antarmuka (Interface)

Antarmuka atau interface sangat mirip dengan kelas, tapi antara antribut kelas tanpa memiliki metode yang dideklarasikan tanpa isi. Deklarasi sebuah metode pada interface dapat diimplentasikan pada kelas lain. Sebuah kelas dapat mengimplentasikan lebih satu antarmuka dimana kelas ini mendeklarasikan metode pada antarmuka yang dibutuhkan oleh kelas itu sekaligus mendefenisikan isinya pada kode program kelas itu. Metode pada antarmuka yang diimplementasikan pada suatu kelas harus sama persis dengan yang ada pada antar muka. Antarmuka atau interface biasa digunakan agar kelas lain tidak mengakses langsung ke suatu kelas, mengangkses antarmukanya.

i. Reusabilily

Pemanfaatan kembali objek yang sudah didefenisikan untuk suatu permasalahan pada permasalahan lainnya yang melibatkan objek tersebut. Misalkan pada sebuah aplikasi peminjaman buku diperlukan pada kelas anggota, maka ketika membuat aplikasi VCD, kelas anggota ini bisa digunakan kembali dengan sedikit perubahan untuk aplikasi penyewaan VCD tanpa harus membuat dari awal lagi.

j. Generalisasi dan Spesialisasi

Menunjukan hubungan antara kelas dan objek yang umum dengan kelas dan objek yang khusus. Misalnya 
kelas yang lebih umum (generalisasi) adalah kendaraan darat dan kelas khusus (spesialisasi) adalah mobil, motor, dan kereta.

k. Komunikasi Antar Objek

Komunikasi antara objek dilakukan lewat pesan (message) yang dikirim satu objek ke objek yang lainnya.

1. Polimorpisme (Polymorphism)

Kemampuan suatu objek untuk digunakan dibanyak tujuan yang berbeda dengan nama yang sama sehingga menghemat baris program.

m. Package

Package adalah sebuah kontainer atau kemasan yang dapat digunakan untuk mengelompokan kelas-kelas sehingga memungkinkan beberapa kelas bernama sama disimpan dalam package yang berbeda.

2. PHP

PHP: Hypertext Preprocessor yaitu bahasa pemrograman web server-side yang bersifat open source. PHP merupakan script yang terintegrasi dengan HTML dan berada pada server (serverside HTML embedded scripting).

PHP merupakan bahasa pemrograman berbasis serverside yang dapat melakukan parsing script php menjadi script web sehingga dari sisi client menghasilkan suatu tampilan yang menarik. Jadi PHP adalah script yang digunakan untuk membuat halaman website yang dinamis. Dinamis berarti halaman yang akan ditampilkan dibuat saat halaman itu diminta oleh client. Mekanisme ini menyebabkan informasi yang diterima client selalu yang terbaru atau up to date. Semua script PHP dieksekusi pada server di mana script tersebut dijalankan.

Popularitas PHP sebagai bahasa pemrograman untuk website sebesar $8.22 \%$ pada pencarian di Google Search dan lebih dari 10 juta website di dunia sudah menggunakan bahasa ini.

Sejak dikembangkan pada tahun 1994, PHP menjadi bahasa komputer yang populer untuk mengembangkan website. Banyak website besar menggunakan bahasa ini sebagai salah satu komponennya. Sebagai contoh Content Management System (CMS) seperti WordPress dan Joomla dibuat dengan bahasa pemrograman dasar PHP. Facebook dan Wikipedia juga menjadi salah satu penggunanya.

Bahasa pemrograman PHP adalah sebuah bahasa script yang tidak melakukan sebuah kompilasi dalam penggunaannya. Web Server yang mendukung PHP dapat ditemukan dimana-mana dari mulai apache, IIS, Lighttpd, hingga Xitami dengan konfigurasi yang relatif mudah. Dalam sisi pengembangan lebih mudah, karena banyaknya milis-milis dan developer yang siap membantu dalam pengembangan.

Beberapa kelebihan PHP dari bahasa pemrograman web, antara lain:

1) Bahasa pemrograman PHP adalah sebuah bahasa script yang tidak melakukan sebuah kompilasi dalam penggunaannya.

2) Web Server yang mendukung PHP dapat ditemukan di mana - mana dari mulai apache,
IIS, Lighttpd, hingga Xitami dengan konfigurasi yang relatif mudah.

3) Dalam sisi pengembangan lebih mudah, karena banyaknya milis - milis dan developer yang siap membantu dalam pengembangan.

4) Dalam sisi pemahamanan, PHP adalah bahasa scripting yang paling mudah karena memiliki referensi yang banyak.

5) PHP adalah bahasa open source yang dapat digunakan di berbagai mesin (Linux, Unix, Macintosh, Windows) dan dapat dijalankan secara runtime melalui console serta juga dapat menjalankan perintah-perintah system.

Bahasa pemrograman PHP merupakan bahasa pemrograman yang kebanyakan digunakan untuk mengembangkan website. Jadi sebenarnya untuk membuat sistem berbasis web tidak harus menggunakan PHP. Namun karena fiturnya yang menarik dan dirasa memudahkan, maka kebanyakan pengembangan menggunakan bahasa pemrograman ini.

Sebelum ada PHP, pengembang kebanyakan menggunakan bahasa pemrograman HTML. Bahasa pemrograman ini sudah dapat membuat tampilan website, akan tetapi tampilan yang dihasilkan masih biasa saja. Biasa saja karena website masih bersifat statis atau tetap, tidak bisa menyesuaikan tampilan dengan kondisi pengguna.

Semenjak adanya PHP maka pembuatan website dapat dikembangkan dan diatur agar menjadi website yang dinamis. Dimana website dapat menyesuaikan tampilan sesuai dengan perangkat yang digunakan oleh pengguna. Tidak hanya itu, website juga dapat melakukan input output dengan database. PHP sendiri biasanya disisipkan ke dalam kode HTML dan dikombinasikan dengan bahasa pemrograman lain, seperti CSS.

3. Framework

Framework adalah sebuah struktur konseptual dasar yang digunakan untuk memecahkan sebuah permasalahan atau isu-isu kompleks. Berikut ini merupakan keuntungan menggunakan framework menurut Daqiqil sebagai berikut:

a. Menghemat Waktu Pengembangan

Penggunaan framework dalam pengembangan suatu software akan mengurangi beban kerja developer, sehingga tidak ada waktu yang terbuang untuk memikirkan fungsi-fungsi umum yang akan digunakan. Selain itu, developer akan lebih fokus pada alur cerita pada aplikasi seperti yang dibutuhkan oleh pengguna. Dengan begitu, waktu pengembangan software akan berjalan lebih cepat dan dapat diserahkan kepada pengguna sesuai dengan waktu yang telah disepakati bersama.

b. Pemrograman menjadi Lebih Terstruktur

Ketika developer menghadapi suatu proyek pengembangan software yang besar, maka akan terdapat banyak program yang ditulis didalamnya. Terkadang, semakin banyaknya program akan menjadikan proses debugging semakin lambat. 
Selain itu, untuk mengecek kode program yang menjadi penyebab terjadinya error akan semakin sulit karena program tidak terstruktur dengan baik. Oleh karena itu, penggunaan framework dapat menjadikan pemrograman menjadi lebih terstruktur sehingga Anda dapat dengan mudah menemukan bagian-bagian dari kode yang perlu diperbaiki. Apalagi, ada framework yang menerapkan konsep MVC (Model View Control) yang memudahkan developer untuk memisahkan dan menyusun program berdasarkan bagiannya, yaitu Model, View ataupun Control.

c. Pengulangan Kode

Seperti yang sudah disinggung pada poin pertama bahwa pembuatan software membutuhkan waktu yang lama, apalagi Anda berperan sebagai programmer tunggal. Maka Anda dapat menggunakan framework untuk mengurangi beban tersebut. Sebab, framework sudah menanamkan berbagai fungsi-fungsi umum yang bisa Anda gunakan tanpa harus mengulangi pembuatan kode dari awal. Pastinya, akan memudahkan Anda juga untuk menggunakannya kembali di proyek-proyek berikutnya.

d. Meningkatkan Keamanan

Keamanan menjadi suatu hal yang sangat vital dalam pengembangan software atau aplikasi. Apalagi, software yang memuat data pengguna yang privasinya harus dilindungi. Disini, framework terus memperbarui versinya yaitu menawarkan fitur yang handal dalam menangani berbagai jenis ancaman yang menyerang sistem keamanan.

Dengan menggunakan framework bukan berarti kita akan terbebas dengan pengkodean. Karena kita sebagai seorang pengguna framework haruslah menggunakan fungsi - fungsi dan variable yang ada di dalam sebuah framework yang kita gunakan. Untuk saat ini framework terbagi dua yaitu framework PHP dan framework CSS, untuk framework PHP terdiri dari

a. Laravel

b. Yii

c. Code Igniter

d. Symfoni

e. Zend Framework

f. Cake PHP

g. Fuel PHP

Dan untuk Framework CSS terdiri dari:

a. Bootstrap

b. Gumby

c. Foundation

d. Less Framework

e. JQuery UI

f. Unsemantic

g. Blue Print CSS

4. MVC

MVC adalah singkatan dari Model View Controller. MVC sebenarnya adalah sebuah pattern/teknik pemograman yang memisahkan bisnis logic (alur pikir), data logic (penyimpanan data) dan presentation logic (antarmuka aplikasi) atau secara sederhana adalah memisahkan antara desain, data dan proses. Adapun komponen-komponen MVC antara lain:

1) Model

Model berhubungan dengan data dan interaksi ke database atau webservice. Model juga merepresentasikan struktur data dari aplikasi yang bisa berupa basis data maupun data lain, misalnya dalam bentuk file teks, file XML maupun webservice. Biasanya di dalam model akan berisi class dan fungsi untuk mengambil, melakukan update dan menghapus data website. Sebuah aplikasi web biasanya menggunakan basis data dalam menyimpan data, maka pada bagian model biasanya akan berhubungan dengan perintahperintah query SQL.

2) View

View berhubungan dengan segala sesuatu yang akan ditampilkan ke end-user. Bisa berupa halaman web, rss, javascript dan lain-lain. Kita harus menghindari adanya logika atau pemrosesan data di view. Di dalam view hanya berisi variabel-variabel yang berisi data yang siap ditampilkan. View dapat dikatakan sebagai halaman website yang dibuat dengan menggunakan HTML dan bantuan CSS atau JavaScript. Di dalam view jangan pernah ada kode untuk melakukan koneksi ke basis data. View hanya dikhususkan untuk menampilkan data-data hasil dari model dan controller.

3) Controller

Controller bertindak sebagai penghubung data dan view. Di dalam controller inilah terdapat class-class dan fungsi-fungsi yang memproses permintaan dari view ke dalam struktur data di dalam model. Controller juga tidak boleh berisi kode untuk mengakses basis data karena tugas mengakses data telah diserahkan kepada model. Tugas controller adalah menyediakan berbagai variabel yang akan ditampilkan di view, memanggil model untuk melakukan akses ke basis data, menyediakan penanganan kesalahan/error, mengerjakan proses logika dari aplikasi serta melakukan validasi atau cek terhadap input.

\section{METODE PENELITIAN}

Jenis penelitian ini adalah eksperimental yaitu dengan melakukan perancangan, pembuatan dan pengujian model sistem. Eksperimen dilakukan untuk mengetahui hasil kerja aplikasi yang kemudian dijadikan sebagai bahan dalam menarik kesimpulan. Data dan informasi yang sesuai dengan fakta dilapangan sangat berpengaruh dalam proses penelitian ini. Dalam penelitian ini proses pengumpulan data dilakukan dengan tiga cara, yaitu:

1. Eksplorasi data melalui internet

2. Studi literatur metode knowledgebased recommendation dan forward chaining yang dilakukan melalui paper, textbook, jurnal, karya ilmiyah dan sumber-sumber ilmiah lainnya. 


\section{Penerapan Konsep Object Oriented Programming Untuk Aplikasi Pembuat Surat}

3. Survei, dilakukan untuk membenarkan permasalahan penelitian yang diajukan.

Metode pengujian yang digunakan dalam penelitian ini yaitu black box. Pengujian Black Box adalah pengujian aspek fundamental sistem tanpa memperhatikan struktur logika internal perangka lunak. Metode ini digunakan untuk mengetahui apakah perangkat lunak berfungsi dengan benar. Pengujian Black Box merupakan metode perancangan data uji yang didasarkan pada spesifikasi perangkat lunak. Data uji dibangkitkan, dieksekusi pada perangkat lunak dan kemudian keluaran dari perangkat lunak dicek apakah telah sesuai dengan yang diharapkan.

Pengujian Black Box berusaha menemukan kesalahan dalam ketegori sebagai berikut:

1. Fungsi-fungsi yang tidak benar atau hilang.

2. Kesalahan Interface.

3. Kesalahan dalam struktur data atauakses database ekternal.

4. Kesalahan lahan kinerja.

5. Inisialisasi dan kesalahan terminasi.

\section{HASIL DAN PEMBAHASAN}

Dalam pembuatan aplikasi ini, diperlukan sebuah basis data yang digunakan sebagai sumber data. Dalam pembuatan basis data, perangkat lunak yang digunakan yaitu mysql. Database dalam aplikasi ini yaitu sebagai berikut:

\begin{tabular}{|l|l|l|}
\multicolumn{2}{|c}{ Tabel 1. Tabel user } \\
\hline \multicolumn{1}{|c|}{ Nama Kolom } & \multicolumn{1}{|c|}{ Tipe Data } & Keterangan \\
\hline id_user & Int (11) & Primari key \\
\hline username & Varchar (128) & \\
\hline password & Varchar (255) & \\
\hline name & Varchar (128) & \\
\hline level & Int (11) & \\
\hline
\end{tabular}

Tabel 2. Tabel dosen

\begin{tabular}{|l|l|l|}
\hline \multicolumn{1}{|c|}{ Nama Kolom } & \multicolumn{1}{|c|}{ Tipe Data } & Keterangan \\
\hline id_dosen & Int (11) & Primari key \\
\hline nama & Varchar (128) & \\
\hline nidn & Int (11) & \\
\hline jabatan & Varchar (128) & \\
\hline status & Varchar (128) & \\
\hline
\end{tabular}

Tabel 3. Tabel mata kuliah

\begin{tabular}{|l|l|l|}
\hline \multicolumn{1}{|c|}{ Nama Kolom } & \multicolumn{1}{|c|}{ Tipe Data } & Keterangan \\
\hline kode_mk & Varchar (128) & Primari key \\
\hline mk & Varchar (128) & \\
\hline sks & Int (11) & \\
\hline semester & Varchar (128) & \\
\hline
\end{tabular}

Tabel 4. Tabel tahun ajaran

\begin{tabular}{|l|l|l|}
\hline \multicolumn{1}{|c|}{ Nama Kolom } & \multicolumn{1}{|c|}{ Tipe Data } & Keterangan \\
\hline id_ta & Int (11) & Primari key \\
\hline ta & Int (11) & \\
\hline
\end{tabular}

Tabel 5. Tabel prodi

\begin{tabular}{|l|l|l|}
\hline \multicolumn{1}{|c|}{ Nama Kolom } & \multicolumn{1}{|c|}{ Tipe Data } & Keterangan \\
\hline id_prodi & Int (11) & Primari key \\
\hline prodi & Varchar (128) & \\
\hline
\end{tabular}

Tabel 6. Tabel dekan

\begin{tabular}{|l|l|c|}
\hline \multicolumn{1}{|c|}{ Nama Kolom } & \multicolumn{1}{|c|}{ Tipe Data } & Keterangan \\
\hline id_dekan & Int (11) & Primari key \\
\hline nama & Varchar (128) & \\
\hline ttd & Varchar (128) & \\
\hline
\end{tabular}

Tabel 7. Tabel surat

\begin{tabular}{|c|c|c|}
\hline Nama Kolom & Tipe Data & Keterangan \\
\hline id_sk & Int (11) & Primari key \\
\hline no & Int (11) & \\
\hline id_dosen & Int (11) & \\
\hline id_prodi & Int (11) & \\
\hline id_ta & Int (11) & \\
\hline semester & Varchar (128) & \\
\hline kode_mk & Varchar (128) & \\
\hline tanggal & Date & \\
\hline
\end{tabular}

a. Halaman login

Berikut ini adalah halaman login aplikasi penilaian persentasi.

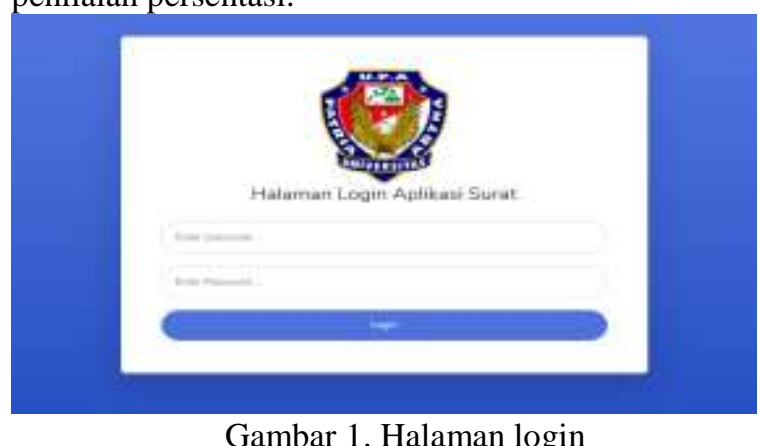

Gambar 1. Halaman login

b. Halaman dashboard

Halaman dashboard ini adalah halaman yang pertaman kali muncul setelah user berhasil melakukan login. 


\section{Penerapan Konsep Object Oriented Programming Untuk Aplikasi Pembuat Surat}

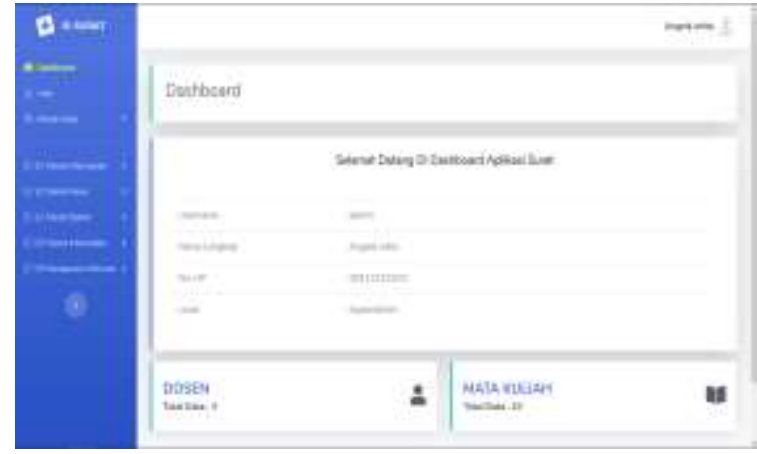

Gambar 2. Halaman dashboard admin

c. Halaman data program studi

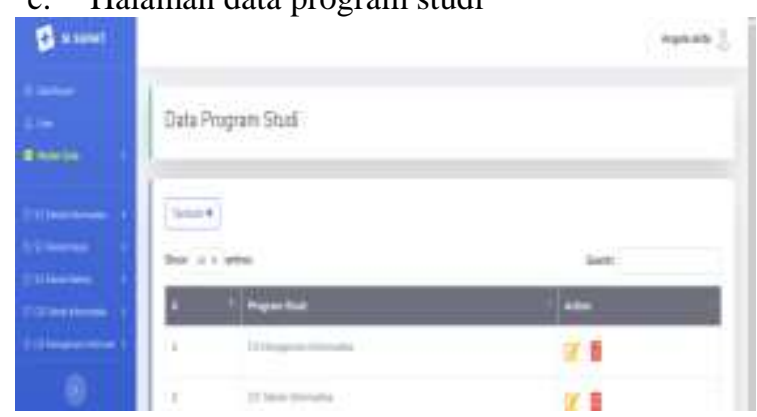

Gambar 3. Halaman data program studi

Aplikasi penilaian persentasi mahasiswa ini bertujuan untuk membuat surat surat keputusan penugasan dosen pengajar dan membuat penomoran secara otomatis. Sebelum membuat surat, user terlebih dahulu memasukan data prodi sehingga setiap prodi dapat membuat surat untuk masing-masing prodi. Kemudian membuat data tahun ajaran, hal ini dikarenakan setiap tahun ajaran baru nomor surat akan kembali direset ke awal

User juga memasukan data dosen dan data mata kuliah, sehingga ketika membuat surat, user tinggal memilih dosen yang mana yang akan diberika surat keputusan penugasan dan mata kuliah apa saja yang diberikan. Sehingga user tidak perlu mengetik data dosen maupun data amat kuliah setiap kali membuat surat.

Aplikasi juga menyediakan pilihan apakah surat langsung dilengkapi dengan tandatangan dari pejabat yang berwenang dalam hal ini dekan atau tandangannya dikosongkan. Oleh karena itu aplikasi ini memiliki form untuk mengupload tandatangan.

Dengan menerapkan konsep OOP, penulisan script menjadi lebih hemat dalam penulisan. Pembuatan operasi-operasi yang sama bisa dikurangi dengan menggunakan fungsi-fungsi. Jadi, dengan membuat satu fungsi, kita kemudian bisa menggunakannya berkali-kali.

Selain itu kita juga mudah dalam mendeteksi error. Dengan oop, dimana operasi-operasi dibedakan berdasarkan class dan fungsi, kita hanya mencari fungsifungsi yang saling berkaitan, dan tentunya hal ini akan jauh lebih menghemat waktu.

Dari hasil pengujian black box yang telah dilakukan untuk menguji modul-modul yang terdapat dalam sistem ini, secara keseluruhan dapat berfungsi dengan baik. Sehingga tujuan pembuatan aplikasi ini dapat terpenuhi.

\section{KESIMPULAN}

Aplikasi yang dibangun dengan menerapkan OOP dapat menghemat waktu dan mudah dalam mendeteksi error. Aplikasi ini sangat membantu dalam pembuatan surat, dikarenakan kita tidak perlu mengetik lagi nama dosen serta mata kuliah yang diberikan penugasan kepada dosen. Aplikasi ini juga membuat penomoran secara otomatis, sehingga dapat menceggah munculnya nomor surat yang sama

\section{DAFTAR PUSTAKA}

[1] W. Anggana, “Aplikasi Pengelolaan Surat Untuk Meningkatkan Kinerja Di Universitas Komputer Indonesia.”

[2] Y. Suherman, "Sistem Informasi Kearsipan Tata Kelola Surat Pada Kantor Inspeksi BRI Kota Padang," J. RESTI (Rekayasa Sist. dan Teknol. Informasi), vol. 1, no. 1, pp. 26-33, 2017.

[3] O. Fajarianto, M. Iqbal, and H. Sanjaya, "Perancangan Aplikasi Untuk Mengecek Perbedaan Lot Barang Ekspor Study Kasus Di PT Victory Chingluh Indonesia," J. SISFOTEK Glob., vol. 8, no. 1, 2018.

[4] H. Irawan, "Perancangan Sistem Informasi Administrasi Kesiswaan pada SMP Negeri 4 Muntok dengan Berorientasi Objek," J. Sifom, 2014.

[5] Anhar. 2010. PHP \& MySql Secara Otodidak. Jakarta: PT TransMedia.

[6] Ardhana. 2012. PHP Menyelesaikan Website 30 Juta! Purwokerto: Jasakom.

[7] Daqiqil. 2011. Framwork Codeigniter. Pekanbaru: Elex media komputindo

[8] Dhanta. 2015. Pengantar Ilmu Komputer, Surabaya: Indah.

[9] Hidatullah dan Kawistara. 2015. Pemrograman Web. Bandung: Informatika

[10] Jogiyanto. 2013. Teori dan Aplikasi Komputer. Yogyakarta: Andi Offet.

[11] Kusrini. 2010. Konsep dan Aplikasi Sistem Pendukung Keputusan. Yogyakarta: Andi Offet.

[12] Nugroho. 2010. Sistem Informasi Manajemen: Konsep Aplikasi dan Perkembangnya. Yogyakarta: Andi Offet.

[13] Rahman. 2013. Cara Gampang Bikin CMS PHP Tanpa Ngoding. Jakarta: PT. Transmedia.

[14] Rosa, A.S dan M. Salahudin. 2013. Rekayasa Perangkat Lunak Terstruktur dan Berorientasi Objek. Bandung: Informatika.

[15] Sibero. 2013. Web Programming Power Pack. Yogyakarta: Mediakom.

[16] Wahana. 2010. Panduan Belajar MySQL Database Server. Jakarta: Mediakita 